\title{
KEANEKARAGAMAN SPESIES DAN KONTRIBUSI HUTAN MANGROVE TERHADAP PENDAPATAN MASYARAKAT DI DESA EYAT MAYANG KECAMATAN LEMBAR KABUPATEN LOMBOK BARAT
}

\author{
Species Diversity End Contribution Of Mangrove On The Community Income In Eyat \\ Mayang Village, Lembar Subdistrict West Lombok
}

\section{Sofian, Muhamad Husni Idris, Markum}

Program Studi Kehutanan, Universitas Mataram

Jl Majapahit No 62, Mataram, NTB

Email ; husni id98@yahoo.com

\begin{abstract}
Eyat Mayang Village in particular Dusun Eyat Mayang Selatan Lembar District is one of the areas that have mangrove potential. This certainly can provide opportunities for people to be able to improve the economy, by maximizing the ecological function of the mangrove. This study aims to determine the variety of mangrove species, as well as various activities of the village community Eyat Mayang District Lembar to support the sustainability of Mangrove Forest. Based on information on the utilization pattern of Mangrove, it is conducted the assessment of household income and income contribution from the activity in community mangrove forest in Eyat Mayang Village. Kecamatan Lembar The determination of the research area is done by purposive sampling based on the consideration that the location is a village and there is a community of mangrove farmers. Data collection was done by observation in the field and direct interviews on the respondents who then analyzed by desktiptif. The results showed that there were 10 different species of mangroves: Rhizophora Stylosa, Rhizophora Apiculata, Rhizophora Mucronata, Lumnitzera Racemosa, Soneretia Alba, Xylocarpus Moluccensis, Xylocarpus Granatum, Bruguiera gymnorrhiza, Sonneratia caseolaris (Fruit Pidada), Avicennia Marina (Fire-fire). Variety of community activities can be described as following the utilization or capture of marine biota inside and outside mangrove forests, nursery and mangrove planting, protection and security, with the total income of households from outside the mangrove forest obtained an average total of Rp. 32.997.058,82 / year / Family and income from within mangrove is Rp. 7.833.529,41 / year / Family. Based on this obtained revenue contribution from mangrove is $19.19 \%$.
\end{abstract}

Key words: Mangrove, Community, Income, Contribution.

\begin{abstract}
Abstrak
Desa Eyat Mayang khususnya Dusun Eyat Mayang Selatan Kecamatan Lembar merupakan salah satu wilayah yang memiliki potensi mangrove. Hal ini tentunya dapat memberikan peluang bagi masyarakat untuk dapat meningkatkan perekonomiannya, dengan cara memaksimalkan fungsi ekologi mangrove tersebut. Penelitian ini bertujuan untuk mengetahui ragam spesies mangrove, serta ragam kegiatan masyarakat Desa Eyat Mayang Kecamatan Lembar untuk mendukung kelestarian Hutan Mangrove. Berdasarkan informasi pola pemanfaatan Mangrove
\end{abstract}


maka dilakukan pengkajian pendapatan rumah tangga serta kontribusi pendapatan dari aktivitas di hutan mangrove masyarakat di Desa Eyat Mayang. Kecamatan Lembar Penentuan daerah penelitian dilakukan secara purposive sampling dengan dasar pertimbangan bahwa lokasi tersebut merupakan desa dan terdapat masyarakat petani mangrove. Pengumpulan data dilakukan dengan cara observasi di lapangan dan wawancara langsung pada responden yang kemudian dianalisa secara desktiptif. Hasil penelitian menunjukan bahwa terdapat 10 ragam spesies mangrove yaitu Rhizopora Stylosa, Rhizopora Apiculata, Rhizopora Mucronata, Lumnitzera Racemosa, Soneretia Alba, Xylocarpus Moluccensis, Xylocarpus Granatum, Bruguiera Gymnorrhiza, Sonneratia Caseolaris (Buah Pidada), Avicennia Marina (Api-api). Ragam kegiatan masyarakat dapat digambarkan sebagai berikut pemanfaatan atau penangkapan biota laut di dalam dan di luar hutan mangrove, pembibitan dan penanaman mangrove, perlindungan dan pengamanan, dengan total pendapatan rumah tangga masyarakat dari luar hutan mangrove diperoleh total rata - rata sebesar Rp. 32.997.058,82/tahun/Keluarga, dan pendapatan dari dalam mangrove adalah sebesar Rp. 7.833.529,41/tahun/Keluarga. Berdasarkan hal tersebut diperoleh kontribusi pendapatan dari mangrove adalah sebesar $19.19 \%$.

Kata Kunci : Mangrove, Masyarakat, Pendapatan, Kontribusi.

\section{Pendahuluan}

Vegetasi mangrove di Indonesia memiliki keanekaragaman jenis yang tinggi, dengan jumlah jenis tercatat sebanyak 202 jenis yang terdiri dari 89 jenis pohon, 5 jenis palm,14 jenis liana, 44 spesies epifit dan 1 jenis sikas. Namun demikian hanya terdapat kurang lebih 47 jenis tumbuhan spesifik hutan mangrove. Paling tidak di dalam hutan mangrove terdapat beberapa jenis tumbuhan dominan yang termasuk ke dalam 4 family yaitu : Rhizophoraceae (Rhizophora, Bruguiera, Ceriops), Sonneratiaceae (Sonneratia), Avicenniaceae (Avicenia) dan Meliaceae (Xylocarpus) (Pieter, Matan, \& Marsono, 2010). Umumnya eksositem mangrove merupakan ekosistem yang kompleks yang terdiri atas flora dan fauna daerah pantai,. Mangrove juga berperan dalam melindungi garis pantai dari erosi, gelombang laut dan angin topan. selain itu, mangrove berperan penting sebagai buffer (perisai alam) dan menstabilkan tanah dengan menangkap dan memerangkap endapan material dari darat yang terbawa air sungai dan yang kemudian terbawa ke tengah laut oleh arus (Murdiyanto, 2003).

Secara garis besar fungsi ekonomis mangrove merupakan sumber pendapatan bagi masyarakat, industri maupun bagi negara. Perhitungan nilai ekonomi sumberdaya mangrove adalah suatu upaya melihat manfaat dan biaya dari sumberdaya dalam bentuk moneter yang mempertimbangkan lingkungan (Arief, 2003).

Hutan mangrove dapat dimanfaatkan oleh masyarakat untuk menambah pendapatan keluarganya. Namun demikian, pengelolaanya harus tetap memperhatikan kelestarian dan fungsi fungsi lain dari mangrove tersebut. beberapa contoh hasil produk pemanfaatan mangrove dapat berupa benda benda hiasan, kerajinan, suvenir dan bahkan untuk kebutuhan perlengkapan sehari hari. Selain itu masyarakat juga sering memanfaatkan kawasan mangrove menjadi tempat $\mathrm{k}$ pembibitan ikan, udang dan berbagai potensi laut lainnya.

Desa Eyat Mayang khususnya Dusun Eyat Mayang Selatan Kecamatan Lembar merupakan salah satu wilayah yang memiliki potensi mangrove. Hal ini tentunya dapat memberikan peluang bagi masyarakat untuk dapat meningkatkan perekonomiannya, dengan cara memaksimalkan fungsi ekologi mangrove tersebut. berdasarkan uraian terkait nilai penting, manfaat serta potensi wilayah mangrove tersebut, maka penelitian yang berjudul "Keanekaragaman Spesies dan Kontribusi 
Hutan Mangrove terhadap Pendapatan Masyarakat di Desa Eyat Mayang Dusun Eyat Mayang Selatan Kecamatan Lembar" ini dilakukan. Adapun tujuan dari penelitian ini adalah untuk mengetahui :(1) ragam spesies mangrove di Desa Eyat Mayang Kecamatan Lembar,(2) ragam kegiatan masyarakat di hutan mangrove di Desa Eyat Mayang Kecamatan Lembar,(3) pendapatan rumah tangga masyarakat di desa Eyat Mayang Kecamatan Lembar,(4) kontribusi pendapatan dari aktivitas di hutan mangrove terhadap pendapatan rumah tangga masyarakat di Desa Eyat Mayang Kecamatan Lembar

\section{Metode}

Penelitian ini merupakan pennelitian deskriptif kunatitatif . yang bertujuan untuk membuat deskripsi, gambaran atau lukisan secara sistematis, faktual dan akurat mengenai fakta-fakta, sifat-sifat serta hubungan antar fenomena yang diselidiki (Nazir, 2011). Penelitian dilaksanakan di Dusun Eyat Mayang Selatan,Desa Eyat Mayang, Kecematan Lembar,Kabupaten Lombok Barat. Penelitian ini dilaksanakan pada bulan juni 2014.

\section{Penentuan Lokasi dan Sampel.}

Pengambilan sampel lokasi penelitian dilakukan secara purposive sampling dengan pertimbangan bahwa kawasan wilayah Eat Mayang merupakan salah satu kawasan yang memiliki potensi mangrove cukup tinggi di wilayah Kabupaten Lombok Barat.dan penentuan responden dilakukan dengan menggunakan teknik aksidental sampling, dimana responden terpilih merupakan responden yang ditemui oleh peneliti pada saat dilapangan (Sugiyono 2012, Arikunto 2006) dan mendapatkan manfaat dari keberadaan mangrove tersebut. Adapun jumlah responden dalam penelitian ini sebanyak 34 kepala keluaga.

\section{Metode Analisis Data.}

1. Indentifikasi jenis mangrove di Desa Eyat Mayang Kecamatan Lembar Kabupaten Lombok Barat dilakukan dengan mengamati secara langsung dan melalui pengambilan specimen yang di peroleh dari lapangan, Identifikasi juga di lakukan dengan menyusuaikan pada buku-buku dendrologi atau literatul lainnya yang terkait.

2. Untuk menganalisis pendapatan kepala keluarga dalam kegiatan usaha pemanfaatan hutan mangrove digunakan rumus sebagai berikut (Hadisapoetra, dalam Leolistari, 2011).

$$
\begin{aligned}
& \text { I = TR - TC } \\
& \text { Dimana : } \\
& \text { I } \quad=\text { Income (Pendapatan) (Rp) } \\
& \text { TR } \quad=\text { Total Revenue (Penerimaan) }(\mathrm{Rp}) \\
& \text { TC }=\text { Total Cost (Total Biaya) }(\mathrm{Rp})
\end{aligned}
$$

3. Untuk mengetahui besarnya kontribusi hutan mangrove terhadap pendapatan masyarakat digunakan rumus sebagai berikut (Dajan dalam Leolistari, 2011) :

$$
\begin{aligned}
& \mathrm{K}=\mathrm{PI} / \mathrm{PT} \times 100 \% \\
& \text { Dimana : } \\
& \mathrm{K}=\text { Kontribusi }(\mathrm{Rp}) \\
& \mathrm{PI}=\text { = Pendapatan dari Mangrove (Rp) } \\
& \text { PT } \quad=\text { Total Pendapatan (Rp) }
\end{aligned}
$$




\section{Hasil dan Pembahasan.}

\section{Gambaran Umum Lokasi Penelitian.}

Desa Eyat Mayang terletak 6 (enam) kilometer dari ibu kota Kecamatan Lembar dan berjarak 15 (lima belas) kilometer disebelah timur ibu kota Kabupaten Lombok Barat, dengan luas wilayah Desa Eyat Mayang mencapai 777,5 Ha (BPD, 2012). Masyarakat Desa Eyat Mayang tersebar di 6 (enam) Dusun yaitu : Dusun Eyat Mayang Utara, Eyat Mayang Selatan, Penyeleng, Jelateng Barat, Lendang Kunyit, dan Khubal Khair. Masyarakat Desa Eyat Mayang secara keseluruhan memeluk agama Islam.

Pendapatan rumah tangga Non Mangrove yang terdapat di Desa Eyat Mayang, Kecamatan Lembar, Kabupaten Lombok Barat seperti pendapatan usahatani (pertanian/sawah dan perkebunan) dan pendapatan non usahatani (dagang/jasa, nelayan, guru, dan lainnya). Nilai hasil hutan non mangrove diperoleh dengan cara menjumlahkan semua pendapatan dari usaha tani dan non usahatani. Untuk lebih jelasnya dapat dillihat pada Tabel berikut.

Tabel 1. Rata-rata Pendapatan Rumah Tangga dari Luar Hasil Hutan Non Mangrove.

Table 1. Average Household Income from Outside Non Mangrove Forest Products.

\begin{tabular}{clcc}
\hline No. & Hasil Hutan Non Mangrove & Rata-rata (Rp/BIn) & Rata-rata (Rp/Thn) \\
\hline 1. & Pertanian/Sawah & $174.264,71$ & $2.091 .176,47$ \\
2. & Perkebunan & $21.568,63$ & $258.823,53$ \\
3. & Dagang/Jasa & $794 . .117,65$ & $9.529 .411,76$ \\
4. Guru Honor & $303.921,57$ & $3.647 .058,82$ \\
5. & Lainnya & $1.455 .882,35$ & $17.470 .588,24$ \\
\hline \multicolumn{2}{r}{ Jumlah } & $\mathbf{2 . 7 4 9 . 7 5 4 , 9}$ & $\mathbf{3 2 . 9 9 7 . 0 5 8 , 8 2}$ \\
\hline \multicolumn{2}{r}{ Rata-rata } & $\mathbf{5 4 9 . 9 5 0 , 9 8}$ & $\mathbf{6 5 . 9 9 . 4 1 1 , 7 6}$ \\
\hline
\end{tabular}

Sumber (Source): Data Primer Diolah Tahun 2014.

Berdasarkan Tabel tersebut dapat disimpulkan bahwa hasil dari luar hutan mangrove diperoleh total rata-rata sebesar Rp. 32.997.058,82/thn. Dimana pendapatan tertinggi diperoleh dari hasil pendapatan lainnya dengan rata-rata sebesar $\mathrm{Rp}$. 17.470.588,24/thn atau Rp. 1.455.882,35/bln. Pendapatan yang diperoleh masyarakat di luar hasil hutan mangrove dapat memberikan nilai ekonomi bagi masyarakat tersebut.

\section{Ragam Species Mangrove}

Pengumpulan data species mangrove pada kawasan Desa Eyat mayang dilakukan dengan metode observasi, dan diperoleh 10 (sepuluh) spesies mangrove yaitu Rhizopora Stylosa, Rhizopora Apiculata, Rhizopora Mucronata, Lumnitzera Racemosa, Soneretia Alba, Xylocarpus Moluccensis, Xylocarpus Granatum, Bruguiera Gymnorrhiza, Sonneratia Caseolaris (Buah Pidada), Avicennia Marina (Api-api).

\section{Ragam Kegiatan masyarakat di Hutan mangrove}

Masyarakat pemanfaat hasil hutan Mangrove melakukan penangkapan terhadap biota-biota perairan yang terdapat di areal hutan mangrove dan sepanjang sungai. Biota yang dimaksudkan seperti ikan, benur/anakan udang, kepiting dan kerang-kerangan. Penangkapan biota oleh masyarakat dilakukan dengan cara tradisional dengan menggunakan peralatan sederhana.

Bentuk kegiatan lain yang dilakukan oleh masyarakat dalam rangka melestarikan dan mempertahankan keberadaan hutan Mangrove adalah dengan cara penanaman secara rutin dan pembentukan komitmen diantara kelompok masyarakat untuk tidak melakukan penebangan Mangrove. 


\section{Pendapatan Responden Di Hutan Mangrove (Dalam dan Luar Mangrove).}

Kegiatan pengambilan biota perairan di Hutan Mangrove yang terdapat di Desa Eyat Mayang, Kecamatan Lembar, Kabupaten Lombok Barat yang dapat memberikan nilai ekonomi langsung adalah pengambilan ikan, udang, dan kepiting. Penilaian pendapatan responden dilakukan dengan menghitung nilai langsung berdasarkan harga pasar komoditas. Nilai hasil hutan mangrove diperoleh dengan cara menjumlahkan semua komoditas yang dimanfaatkan oleh masyarakat. Untuk nilai komoditas yang dimanfaatkan oleh masyarakat dapat dilihat pada table berikut

Tabel 2 . Pendapatan Hasil Hutan Mangrove yang di Manfaatkan Masyarakat.

Table 2. Mangrove Forest Product Revenue Used by the Community.

\begin{tabular}{|c|c|c|c|c|}
\hline \multirow[t]{2}{*}{ No } & \multirow[t]{2}{*}{ Jenis Hasil Hutan Mangrove } & \multicolumn{2}{|c|}{ Rata-Rata Nilai Produksi } & \multirow{2}{*}{$\begin{array}{c}\text { Total } \\
\text { Pendapatan } \\
\text { (Rp / Tahun }\end{array}$} \\
\hline & & $\begin{array}{c}\text { Dalam } \\
\text { (Rp/Tahun) }\end{array}$ & $\begin{array}{c}\text { Luar } \\
\text { (Rp/Tahun) }\end{array}$ & \\
\hline 1 & Nilai Ikan & $2.002 .941,18$ & $441.176,47$ & $2.444 .117,65$ \\
\hline 2 & Nilai Udang & $2.059 .411,76$ & $435.882,35$ & $2.495 .294,11$ \\
\hline 3 & Nilai Kepiting & $2.364 .705,88$ & $529.411,76$ & $2.894 .117,65$ \\
\hline & Jumlah & $6.427 .058,82$ & $1.406 .470,59$ & $7.833 .529,41$ \\
\hline
\end{tabular}

Sumber (Source) : Data Primer Diolah Tahun 2014.

Berdasarkan data tersebut rata-rata pendapatan masyarakat yang berasal dari hutan mangrove sebesar Rp. 7.833.529,41/tahun, dengan nilai yang terbesar adalah nilai kepiting yaitu sebesar Rp. 2.894.117,65/tahun (36,95\%). Hal ini dapat disebabkan karena harga jual kepiting relatif mahal menyebabkan nilai kepiting yang didapat lebih tinggi dibandingkan dengan jenis komoditas lain, dimana harga jual kepiting perkilogram sebesar Rp. 40.000/kg - 70.000/kg, sedangkan harga ikan dan udang perkilogram hanya sebesar Rp. $20.000 / \mathrm{kg}-30.000 / \mathrm{kg}$.

\section{Pendapatan Total Masyarakat.}

Rata-rata pendapatan total responden adalah sebesar Rp. 40.830.588,23 pertahun yang diperoleh dari penjumlahan dari rata-rata pendapatan dari hutan mangrove dan diluar kawasan Non mangrove. Untuk lebih jelasnya dapat dilihat pada tabel berikut ini.

Tabel 3. Rata-rata Pendapatan Rumah Tangga Masyarakat dari Total Responden di Dusun Eyat Mayang Selatan, Desa Eyat Mayang, Kecamatan Lembar, Kabupaten Lombok Barat.

Table 3. Average Household Revenue from Total Respondents in Dusun Eyat Mayang Selatan, Eyat Mayang Village, Lembar District, West Lombok District.

\begin{tabular}{clcc}
\hline No. & Sumber Pendapatan Rumah Tangga & $\begin{array}{c}\text { Rata-rata } \\
\text { (Rp/thn) }\end{array}$ & Persentase (\%) \\
\hline 1. & Pendapatan di Dalam Hutan Mangrove & $6.427 .058,82$ & 15.74 \\
2. & Pendapatan di Luar Hutan Mangrove & $1.406 .470,59$ & 3.44 \\
3. & Pendapatan di Luar Laut (Nelayan) & $32.997 .058,82$ & 80.82 \\
\hline \multicolumn{2}{c}{ Total } & $\mathbf{4 0 . 8 3 0 . 5 8 8 , 2 3}$ & $\mathbf{1 0 0}$ \\
\hline
\end{tabular}

Sumber (Source): Data Primer Diolah Tahun 2014.

Dari tabel di atas, menunjukkan bahwa secara umum pendapatan rumah tangga masyarakat Dusun Eyat Mayang Selatan dari pendapatan dalam hutan mangrove (ikan, udang, dan kepiting) diperoleh rata-rata pendapatan sebesar Rp. $6.427 .058,82 /$ thn $(15,74 \%)$, pendapatan yang diperoleh dari laut luar hutan mangrove sebesar Rp. 1.406.470,59/thn (3,44\%), dan pendapatan responden dari luar laut yaitu usahatani (pertanian/sawah dan perkebunan) dan pendapatan non usahatani 
(Dagang/Jasa, Nelayan, Guru, dan Lainnya) adalah rata-rata sebesar Rp. 32.997.058,82/thn (80,82\%). Jadi, total rata-rata pendapatan responden baik pendapatan dari dalam hutan mangrove maupun luar hutan mangrove adalah sebesar Rp. 40.830.588,23/tahun.

\section{Kontribusi Terhadap Pendapatan Rumah Tangga Masyarakat.}

Kontribusi yang dimaksud dalam penelitian ini adalah Rata-rata pendapatan dari pemanfaatan hutan mangrove diperoleh sebesar Rp. 7.833.529,41/tahun, sedangkan pendapatan dari luar pemanfaatan hutan mangrove yaitu usahatani (pertanian/sawah dan perkebunan) dan pendapatan non usahatani (Dagang/Jasa, Guru, dan Lainnya) adalah rata-rata sebesar Rp. 32.997.058,82, sehingga didapat sumbangan atau kontribusi rata-rata sebesar 19,19\%.

Berdasarkan data tersebut dapat diperoleh kesimpulan bahwa hasil pemanfaatan hutan mangrove tidak memberikan kontribusi kepda masyarakat sekitar Dusun Eyat mayang Selatan dan sebagaian besar masyarakat tidak menggantungkan pendapatan dari hasil pengelolaan hutan mangrove.

\section{Kesimpulan}

1. Terdapat 10 spesies mangarove di Dusun Eyat Mayang Selatan, Desa Eyat Mayang, Kabupaten Lombok Barat yaitu Rhizhophora stylosa, Rhizhophora apiculata, Rhizhophora mucronata, Lumnitzera racemosa, Soneratia alba, Xylocarpus moluccensis, Xylocarpus granatum, Bruguiera gymnorrhiza, Soneratia caseolaris (buah pidada), Avicennia marina (api - api)

2. Kegiatan yang dilakukan masyarakat di Dusun Eyat Mayang Selatan, Desa Eyat Mayang, Kabupaten Lombok Barat meliputi; Pemanfaatan atau penangkapan biota laut didalam dan diluar hutan mangrove, Masyarakat melakukan pembibitan dan penanaman mangrove, Perlindungan dan pengamanan, Inventarisasi dan monitoring potensi jenis yang dimanfaatkan oleh masyarakat.

3. Rata-rata pendapatan masyarakat di Desa Eyat Mayang, Kecamatan Lembar Kabupaten Lombok Barat dari usaha kegiatan mangrove sebesar Rp.7.833.529,41/tahun dari 17 responden yang memanfaatkan hasil hutan mangrove.

4. Kontribusi pendapatan responden dari kegiatan dalam mangrove terhadap pendapatan rumah tangga sekitar $19,19 \%$.

\section{DAFTAR PUSTAKA}

Arief, A. 2003. Hutan Mangrove Fungsi dan Manfaatnya. Kanisius. Yogyakarta.

Arikunto, S. 2006. Prosedur Penelitian. Rieneka Cipta. Jakarta.

Bengen, D. G. 2001. Pedoman Teknis Pengenalan dan Pengolaan Ekosistem Mangrove, Pusat Kajian Sumberdaya Pesisir dan Lautan .IPB. Bogor.

Leolistari. 2011. Analisis pendapatan dan kontribusi hasil hutan bukan kayu (HHBK) petani HKm di Desa Sesaot Kecamatan Narmada Kabupaten Lombok Barat. Fakulatas Pertanian. Universitas Mataram.

Murdiyanto, B. 2003. Mengenal, Memelihara dan Melestarikan Ekosistem Bakau. Departemen Kelautan dan Perikanan. Jakarta.

Nazir, M. 2011. Metode Penelitian. Penerbit Ghalia Indonesia. Jakarta..

Pieter, O., Matan, M., \& Marsono, D. (2010). Keanekaragaman Dan Pola Komunitas Hutan Mangrove Di Andai Kabupaten Manokwari. Majalah Geografi Indonesia, 24(1), 36-53. Retrieved from https://jurnal.ugm.ac.id/mgi/article/view/13340/9558

Sugiyono. 2012. Metode Penelitian Kuantitatif Kualitatif dan $R \& D$. Alfabeta. Bandung. 